\title{
Increasing Students' Speaking Ability in Procedure Text by Using Cooperative Learning
}

\author{
Siti Rohemah' ${ }^{1}$, Fabiola D. Kurnia ${ }^{2}$, Eka Fadilah ${ }^{3}$ \\ ${ }^{1,2,3}$ STKIP PGRI Sidoarjo, Indonesia \\ ariesema.sr@gmail.com,fabkurnia@gmail.com,mref3k4@gmail.com
}

\begin{abstract}
It was the primary objective of this classroom action research project to improve students' oral communication skills in procedure text by utilizing cooperative learning. Statistical analysis was performed on the data in this study, using both quantitative and qualitative data. The fluency, performance, and completeness of the students' task are the primary focus of this study. The subjects of the study were students in the ninth grade of Junior High School YAS'A Sumenep, who participated in the study. The score of the students was used as the basis for this investigation. This research employed a two-cycle approach that included planning, implementing, observing, and reflecting. The findings of this study revealed that students were enthusiastic about cooperative learning when it was implemented as a method over a two-cycle period. It can be concluded that cooperative learning increased student speaking ability because 95 percent of the students who passed the Criteria Minimum Score (KKM) achieved success in their scores, and that cooperative learning increased student speaking ability because it increased student speaking ability.
\end{abstract}

Keywords speaking; procedure text; cooperative learning

\section{Introduction}

English is the second language that is taught to students in every school in Indonesia, and it is the most widely spoken language in the world. It consists of four skills that students must master in order to pass the test: writing, listening, reading, and speaking. Among the most important skills to acquire when learning a second language is the ability to communicate effectively. Because speaking has become a gauge of one's understanding and ability in a new language that one has learned. As Bueno, Madrid, and Mclaren point out in Rao's journal (RAO, 2019), "Speaking is one of the most difficult skills that language learners must learn." Speaking is considered to be the most important of the four language skills in English, and it is the most difficult to master. Even the language learners take a long time to learn the language.

"Speaking is one of the most important skills in language learning (Sulistyaningsih, 2018)." People can communicate information and ideas to one another through speech, and they can also maintain social relationships by communicating with one another." According to Resi Rahmanis (2019), who writes in her journal, "Speaking is an important part of foreign language learning and teaching because it allows students to express their ideas orally in a foreign language." They will remain silent if they lack communication skills. In order to communicate effectively, they must put their abilities to the test in everyday situations. 
As a result, when students are learning a second language (in this case, English), they must take the initiative in leading the conversation. While, at times, students are apprehensive about speaking up in class. Because they are afraid of making mistakes, they are afraid their friends will make fun of them. It is also supported by Eka Nursanti et al (Nursanti, 2014), who write in their journal that it occurred as a result of poor mastery of grammar and vocabulary, as well as error production in pronunciation, fluency, and comprehension.

To solve some the problems above, teachers must have some statregies to increase the student's speaking ability. Hence in this study, the writers used cooperative learning to increase students'ability. By cooperative learning, students can solve their afraid to speak in fornt of the class. It is supported by macaro's statement in Arta's journal, "Collaborative learning is a process of learning in which students collaborate together to attain 'common learning goals' ( (Arta, 2018)

Besides that, cooperative learning is suitable to be applied in one of the chapter which is enlisted sillabus of nine grade that is procedure text. Procedure text is a text which tells how to make or to do something. The students can retell the text by speaking the structure such as, goal, material, and steps. Same like eka's journal (Nursanti, 2014) "text is a kind of text that tells the reader how to make or operate something in sequence steps. It is also supported by (Hermanis, 2019) in her journal, "procedure text usually practice how to make something or how something can be done".

This research has been done by two people who has same same material that are procedure text, first is Eka Nursanti and friends and the second is Resi Hermanis. This research was made in the same thing, that is about improving speaking ability by using procedure text as the tool. While, there are some differences among this research, for instance the level. Eka Nursanti and Resi Hermanis examined senior high school students, so that Resi Rahmanis just describes about speaking skill by using procedure text and Eka Nursanti examine about the improving the speaking ability which means that the students have had experience about speaking. Otherwise this research examines junior high school students who still need support and motivation to speak in a small group not individually. Thus, relating to the statement, this research question formulated is "How is the increasing of the students" speaking ability in procedure text by using cooperative learning at junior high school?." Also this research is expected giving information about how to increase student's ability in speaking by using cooperative learning in nine grade students and enrich knowlegde to the students, teachers and the next researcher about speaking. Especially to the teachers, this study will enrich the teacher's knowlegde how to increase students' ability in speaking and how to motivate students. Beside that to the students, this study will enrich them to be motivated how to learn english espesially in speaking. Beside that, the students also learn how to study with team work. Moreover, this study is expected to inspires the next researcher who is going to do class action research in the same field.

\section{Review of Literature}

\subsection{Cooperative Learning}

In cooperarive learning, teachers decide some students into several groups. In order to make the students learn the lesson easily, they can share what the knowlegde that they get. Also they can help each other if one of them do not understand about the lesson. Hence they can get what the purpose of the lesson. It is supported by Johnson's \& Smith's opinion in (Attamimi, 2014 )" a teaching technique where students work in groups on a certain activity in order to maximize one another's learning and to achieve certain goals." 
Previous theory also supported by Renandya's theory. Based on Renandy, "Cooperative learning involves students in helping each other learn and helping each other enjoy and become more skillful in the learning process. Belief in the power of cooperation, i.e., that "two heads are better than one," that "many hands make 81 Student Centered Cooperative Learning: An Introduction light the work," and that "if you want to go fast, go alone; but, if you want to go far, go together," goes back thousands of year." (Renandya, 2019).

Based on Renandya's statement, cooperative learning is good solution to solve students' problem in teaching learning process. In cooperative learning, students can discuss what they are difficulties in one lesson. Students who do not understand about the lesson can ask to the students who understand well about the lesson. Hence in Renandya's theory mention that" two head better than one head." This theory is also supported by Digby. Based on Digby, " cooperative situations, students are bound together by their mutual fate, shared identity, and mutual causation and, therefore, celebrate (and feel benefited by) each other's successes. Relevant ideas, information, conclusions, and resources tend to be made available, exchanged, and utilized in ways that promote collective and individual insights and increase energy to complete the task." (Digby, 2013).

\subsection{Speaking}

People like speaking. They will refer speaking rather than writing because by speaking people can communicate with another. They will show what they like and don't,this statement is supported by theory (Hughes, 2011) "Speaking is more fundamentally linked to the individual who produces it than the written form is."

Based on (Hermanis, 2019) in her journal, " Speaking is a crucial part of the foreign language learning and teaching, because it can be used for the students to express their ideas orally in foreign language. Without speaking skills, they will just keep silent. In order to speak well, they must practice their skill in everyday live." According to the theory, it can be concluded that teachers must support the students to speak in the class whether they get wrong or not Because They will be active in the class o respond what the teacher said if they understand. Otherwise they will be vacum if they do not understand what will they said.

Furthermore based on Raos' opinion, Speaking skills are the most essential skills for all the learners who wish to learn English to enhance their career, improve business, build confidence levels, get better job opportunities, make public speeches, attend interviews, participate in debates and group discussions, give presentations and so on." (RAO, 2019)

\subsection{Procedure Text}

Based on Anderson and Kathy in jounal of Lusiana explained that " a procedure is a piece of text that tells the reader or listener how to do something (Lusiana, 2013). It is also supported by one of website which is source to lear english. It explains that Procedure text : (1)Texts that explain how something works or how to use instruction / operation manuals e.g. how to use the video, the computer, the tape recorder, the photocopier, the fax. (englishindo, 2017)

In Eka Nursanti's journal also expain that "Procedure text is a kind of text that tells the reader how to make or operate something in sequence steps. " (Nursanti, 2014) . It is also supported by (Hermanis, 2019) in her journal, "procedure text usually practice how to make something or how something can be done".

\section{Research Methods}

This research is classroom action research where students and teachers activities in clas XI-4 Yas'A Junior High school as the source of the data in this research. Classroom action 
research-based instruction defined as the teaching and learning process by emphasizing that the research process has two related parts which are the research process and the research result (Parinya Meesuk, 2020). Then score of the students' activities is the data of this research. Therefore, the data which had been collected, then it was presented by quantitative and qualitative data.

\subsection{Respondent}

This research was taken in YAS'A Junior High School Sumenep which was students in nine grade as the respondents of this research. Cooperative learning was used as the stategy in this research because the respondents of this research had different knowledge and ability in speaking. There were student who excellent, good and bad ability.

\subsection{Instrument}

To collect the data, the reseacher used some data instruments to support this research, such students' score which was obtained form students' test presentation and students' task.

\subsection{Procedure Collecting Data}

In collecting data, some procedures was implemented:

a. Collecting and Correcting the Result of Students' Task

Researcher was asked the students to submit the assignment and correcting the structure and grammar.

\section{b. Students Presentation}

To test their understanding and fluenty students' speaking, they had to present their assignment in front of the class (Attamimi, 2014 ).

\section{c. Documentation}

In order to motivate the students' in their speaking and as the research evidence, researcher did the documentation.

\section{d. Scoring}

Scoring was used to determine the average score which was gotten by the student and to determine they passed the minimum score or not.

\subsection{Data Analysis}

This research used qualitative and quantitative data. Qualitative data in this research was obtained during the implementation of the teaching learning process (Corte, 2019). Having collected the data from students'task, and student's presentation. Writer analyzed the data. First writer checked the students' structure of the procedure text. Also it was seen the correct steps and grammatical. After that, the writer gave score to the task. Second writer checked score based on the observation checklist and account the score. While quantitaive data was obtained from result of the teaching learning process which was performed by scoring. (Ahmad, 2019). The writer accumulated two scores, students' task and observation checklist. Then the score divided the score based on the formula which has arranged. Hence, the writer got the avarage of the score. The last step, the writel make list the score from the high score untill the lower score.

Completing this study, writer collaborated with on of english teacher in Yas'a Junior high school who was a observer in teaching learning process in this research. To compile the process of achievement of the students' ability, this research involved into four phases, 
planning, implementing, observing and reflecting which each cycles were essential as proposed by Kemmis and McTaggart (Yolenta Wea, 2019) .

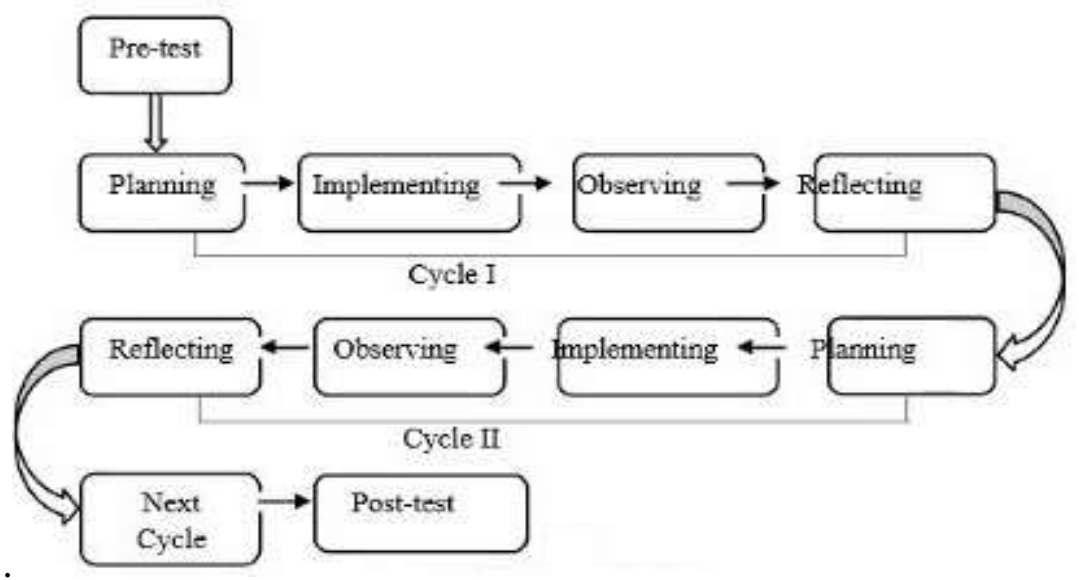

Figure 1. Four Phases by Kemmis and McTaggart (Yolenta Wea, 2019)

Planning, in this phase the researcher identifyies a problem or issue and develop a plan of action in order to bring about improvement in specific area of the research context. Action is a phase the writer apply the plan. Observation, in this phase the writer see how the process working and make a note or assessment of student' performance. Reflection In this phase the writer studies what have done and reflect it for students' learning.

This research considered success if the students had pass the score minimum (75) which the score measured based on the criterias such as: The fluency of the speaking, the correct pronounciation, the clear voice, correct and complete text, such as the criterias as below:

Table 1. Score Measured Based on the Criterias

\begin{tabular}{|c|c|c|c|c|c|}
\hline \multirow[t]{2}{*}{ No } & \multirow[t]{2}{*}{ Criteria } & \multirow[t]{2}{*}{ Description } & \multicolumn{3}{|c|}{ Score } \\
\hline & & & A & $\mathrm{b}$ & $\mathrm{C}$ \\
\hline \multirow[t]{3}{*}{1.} & \multirow[t]{3}{*}{ Fluency } & Clear and Correct pronounciation & & & \\
\hline & & Clear and incorrect pronounciation, & & & \\
\hline & & Unclear and incorrect pronounciation & & & \\
\hline \multirow[t]{3}{*}{2.} & \multirow[t]{3}{*}{ Performance } & Confident and serious & & & \\
\hline & & Serious but unconfident & & & \\
\hline & & Unserious but unconfident & & & \\
\hline \multirow[t]{3}{*}{4.} & \multirow{3}{*}{$\begin{array}{l}\text { The text } \\
\text { completeness } \\
\text { (Students' } \\
\text { Task) }\end{array}$} & $\begin{array}{l}\text { Complete structure and correct sentence } \\
\text { grammatically }\end{array}$ & & & \\
\hline & & $\begin{array}{l}\text { Complete structure but incorrect } \\
\text { sentence grammatically }\end{array}$ & & & \\
\hline & & $\begin{array}{l}\text { Uncomplete structure and } \\
\text { uncomplete steps }\end{array}$ & & & \\
\hline
\end{tabular}

Score
$\mathrm{A} \quad=85-100$
$\mathrm{B} \quad=75-80$
$\mathrm{C} \quad=50-70$ 
To measure student's score:

$\mathrm{X}=\frac{F S+A S+S T S}{3}$

Note :

$\mathrm{X} \quad=$ Student' score

FS = Fluency' score

PS = Accuracy' score

STS = Student's task' score

\section{Discussion}

\subsection{Result}

The aim of this research was answering a problem which happens in nine grade students about the increasing of the students' speaking ability in procedure text by using cooperative learning. like the explaination in the method, this research was conducted in two cycle. First cycle was conducted on $16^{\text {th }}$ and $23^{\text {th }}$ february 2021 which each meeting taken 2 hours.

\section{a. First Cycle Description}

In this cycle consisted in four steps, they were planning, implementing, observing and reflecting. For planning in first cycle, teacher as a writer of this research prepared the new materi about the procedure text. Teacher prepared microsoft power point to be presented in fornt of the class and absent. First teacher entered the class and began the class with greeting the students, and absent the students one by one. Next the teacher opened the powerpoint and gave the students little discussion about the new materi. Then teacher explained about the procedure text, the generic structure and the grammatical structure. Beside that teacher gave the students example the procedure text to made the clearer. In the end of the class, teacher devided the students into five groups which was each groups consisted in five students. Teacher asked them to make procedure text which topic "how to do something". Teacher gave a freedom to each groups to make their material. After finishing made the task procedure, each group had to submit the result of the text. Then teacher corrected the text based on the correct grammar. In the end of the class, teacher gave the feedback of the groups' assignment and also infomed that next meeting was pre- test where they had to present their assignment infont of the class orally and the activities would be recorded to upload in the social media. In the second meeting which was conducted on $23^{\text {th }}$ Februari 2021, teacher and collaborator (observer) conducted the implementation in the previous meeting.

Based on the result of implementation in first cycle, it could be concluded that some of students were enthusiastic for the speaking ability, but they were unconfident when they were infornt of the class. They were not serious because they afraid to speak in front of the class. Thus, in this cycle was still found that there were $50 \%$ of the students in each groups who could not pass the minimum score (65-70)and 50\% of the students got minimum score (75). Since there were many students who did not pass the standart minimum score, this cycle was not successfull. Therefore the teacher and observer agreed to continue in the second cycle with new method. 


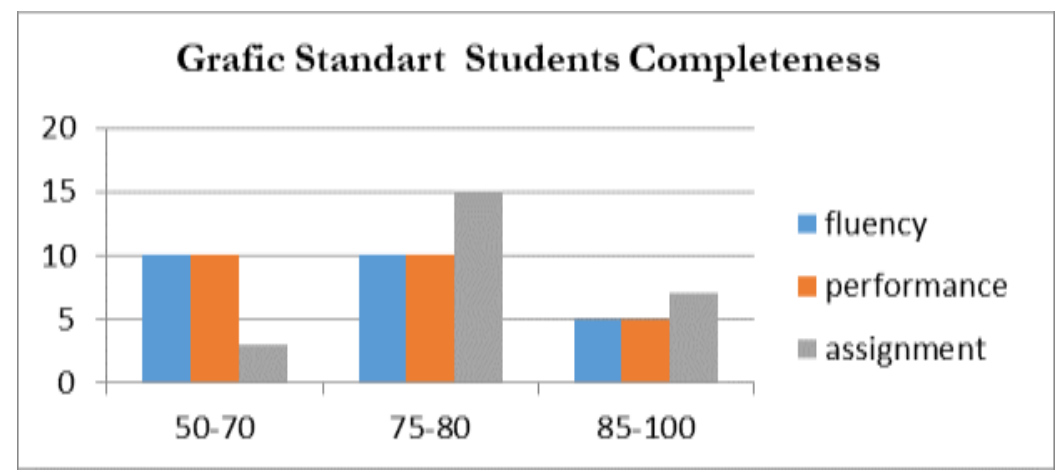

Figure 2. Grafic Standart Students Completeness

\section{b. Description in Second Cycle}

Same as the first cycle, this cycle also conducted in two meeting. First meeting was on $2 \mathrm{t}^{\mathrm{h}}$ march and $9^{\text {th }}$ 2021. In this cycle, teacher changed the method in cooperative learning. The teacher planned to change the group into small groups where in the first cycle the students devided into five groups which each groups consisted into five students. Then teacher planned to change the them into small groups which the class devided into eigh groups. Each groups consisted into three students but there was one groups which consisted into four students.

In implementation for first meeting in second cycle. Teacher entered to the class and opened the class with greeting and pryaing. Teacher gave some reflection in first cycle. Teacher explained about the new method that would be used in this cycle. 1) teacher changed the groups into small groups and teacher choosed the students who passed the minimum score in first cycle. 2) teacher informed the new theme that was " how to make something" where in this theme teacher determined they had to make food or drink by using steps of procedure text. Then the students had to bring the real tools and they could drink and eat what they made. 3) teacher asked the students to sit with the new groups and made the task of procedure text based on their own planning and the had to submit the task. 4) in the end of the meeting, teacher give feed back to their assignment and also informed that they had to prepared the presentation in the next meeting as the post-test. In the next meeting which was conducted on the $9^{\text {th }}$ march 2021. Teacher, students and observer implemented the presentation and teacher did not forget to record the activities as the documentation of the post- test and the teacher uploaded in facebook due to Yas'a junior high school is islamic boarding school ,the students could not use handphone, thus they could see their performance in Facebook when they came home. Beside that in the end of the meeting the students, observer and teacher ate and drunk the result of their cooking together.

In the result of this cycle was so amazing. The students were more enthusiastic that cycle 1 . Therefore, this cycle was successfull because most of the students perfomed the speaking like what the teacher expected. $20 \%$ of the students got minimum score (75) and $75 \%$ students got upper the minimum score (80-85) only two students who could pass the standart score minimum. Seeing the result teacher and observer agreed that this classroom research could be stopped. 


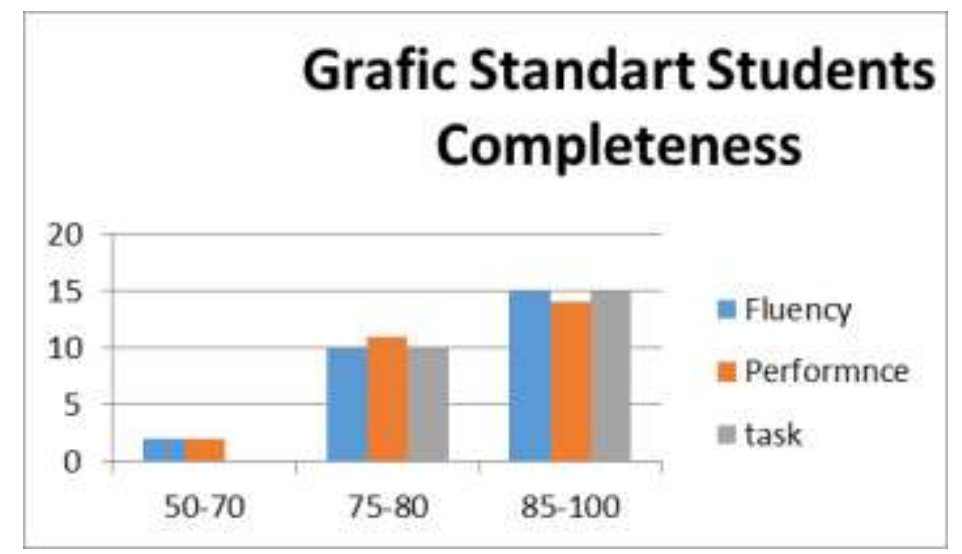

Figure 3. Grafic Standart Students Completeness

\subsection{Discussion}

To increase students' speaking ability, the teacher who was the writer used cooperative learning which the student. This research have been done in two cycle where in the first cycle was conducted in 2 meeting. In first cycle students devided into five groups which consisted in five students. While in this cycle, most of the students didnot pass the standart score minimum because in their presentation, most of students were not serius. Some of them felt shy because they could not pronounciate the vocabulary correctly. Another students were not confident to speak in fornt of the class, they still read the text more than speaking. Therefore from the pre-tes score, most of the students $(50 \%)$ could not pass the standart minimum score. Seeing the result, teacher and observer agreed that must be held second cycle. This deficiency arises due to the lack of attention of educational personnel printing institutions that pay attention to these skills (Waluyandi, 2020). Pohan (2020) states that at school, from elementary to secondary school or even college, students undergo, practice, and experience the learning process of various knowledge and skills. Learning is essentially a cognitive process that has the support of psychomotor functions (Arsani, 2020).

In the second cycle, writer changed the method of the cooperative learning. Students' group changed into small groups which consisted to three students in each groups. So there were eight groups in the class. Then teacher asked the students to bring real tools based on their text procedure. This method was more condusive than first method and the students were more enthusiastic because some facts were found. 1) in small groups, students could devide based on the generic structure of the procedure text, means that one students could present the goal of their presentation and the others could present the in gredients and steps. 2) by using real tools, students more confident to speak because they could remember the tools and the steps. Therefore in this cycle there was increasing students' speaking ability significantly because it could be seen from the students' score which $20 \%$ of the students got minimum score (75) and $75 \%$ students got upper the minimum score (80-85) only two students who could pass the standart score minimum. Due to in the second cycle had considered successfull, so this research would not continue to the next cycle.

Although increasing students speaking had been reseached by two different researchers in the same text, they are Eka Nursanti and Resi Hermanis. Nevertheless, this research was so diffrent from them. This research used cooperative learning method. Where this was more confortable to be used to increase speaking ability in text procedure text because by cooperative learning, students could share their difficulties in speaking and in procedure, they could practise their speaking by using real tools. 


\section{Conclusion}

\subsection{Conclusion}

In light of the findings of the research, it is possible to conclude that first and foremost, students are afraid to speak in front of the class because they lack confidence and are afraid of making a mistake in their pronounciation. Consequently, the teacher implemented several strategies to improve students' oral communication skills, including cooperative learning and realtools to assist students in speaking. Then, this research was conducted in two cycles, with the first cycle resulting in a good score for both the teacher (writer) and the observer, which was higher than the standard minimum score. Whereas, in the second cycle, $95 \%$ of students achieved the required minimum score $(\mathrm{KKM})$. This research was therefore deemed successful, and it was not carried forward to the next cycle of investigative process.

\subsection{Suggestion}

In light of the findings, there is only one recommendation to the next researcher that can be used to improve the quality of the current research. Next researchers can use the same method (cooperative learning) and material (procedure text) as the previous researcher, but the next researchers can use Vlog media to arouse more interest in students which related to cooperative learning approach.

\section{References}

Ahmad, S. (2019). Qualitative v/s. Quantitative Research- A Summarized Review. Journal of Evidence Based Medicine and Healthcare $\bullet$, 1-6.

Arsani, et.al. (2020). Differences in Motivational Orientation in Physical Education in terms of Gender Differences. Budapest International Research and Critics in Linguistics and Education (BirLE) Journal Vol 3 (3): 1428-1434.

Arta, B. (2018). Multiple Studies: The Influence of Collaborative Learning Approach on Indonesian Secondary High School Students' English-Speaking Skill. English Language Teaching Educational Journal (ELTEJ), 1-12.

Attamimi, N. O.-T. (2014 ). Effectiveness of Cooperative Learning in Enhancing. International Journal of Linguistics , 1-20.

Corte, P. A. (2019). What is Qualitative in Qualitative Research. - , 1-22.

Digby, J. E. (2013). Secondary School and Cooperative Learning. New york: Routledge.

englishindo. (2017). Retrieved july wednesday, 2021, from englishindo: https://www.englishindo.com/2014/04/procedure-text.html

Hermanis, R. (2019). Students' Speaking Skill Of Procedure Text At Xi Grade Of Social Sciences 2 Of Sman 1 Kampar journal.

Hughes, R. (2011). Teaching and Researching second Edition. Great Britain: Pearson Education Limited.

Lusiana. (2013). A Study on the Students' Ability in Writing Procedure. 1-11..

Norton, L. S. (2009). Action Research in Teaching Learning. canada: Routledge.

Nursanti, E. (2014). Improving Speaking Ability In Procedure Text By Using Retelling Technique. .

P.Pelton, R. (2010). action research for teachercandidate. united stated: A division of Rowman \& Littlefield Publishers, Inc.

Parinya Meesuk, B. S. (2020). Classroom Action Research-based Instruction:The Sustainable Teacher Professional. Journal of Teacher Education for Sustainability, , 1-13.

Pohan, A.M., Asmin, and Menanti, A. (2020). The Effect of Problem Based Learning and Learning Motivation of Mathematical Problem Solving Skills of Class 5 Students at 
SDN 0407 Mondang. Budapest International Research and Critics in Linguistics and Education (BirLE) Journal Vol 3 (1): 531-539.

RAO, P. S. (2019). The Importance f Speaking Skills In English Classrooms. Alford Council of International English \& Literature Journal(ACIELJ) , 1-14.

Renandya, G. M. (2019). Student Centered Cooperative Learning Linking Concept in Education to Promote Students Learning. Singapore: SpringerBriefs in Education.

Secondary School and Cooperative Learning. (2013). New York: Routledge.

Sulistyaningsih. (2018). Teaching Speaking by group discussion for tenth graders. sulistyaningsih STKIP PGRI SIDOARJO , 1-7.

Waluyandi, F., Trihastuti, R., and Muchtarom, M. (2020). Implementation of Parental Involvement in Learning Civic Education. Budapest International Research and Critics in Linguistics and Education (BirLE) Journal Vol 3 (4): 1686-1695.

Yolenta Wea, V. L. (2019). Improving the Eight Grade Students' Competence in Using Question Tags through Discussion Method. Kairos Elt Journal , 1-24. 